\title{
Determinants of Brand Equity in Automobile Producing
}

\section{Companies in China}

\author{
Davit Mkhitaryan ${ }^{1}$ \\ ${ }^{1}$ School of Management, Wuhan University of Technology, Wuhan, China \\ Correspondence: Davit Mkhitaryan, N1 Building, West Mafangshan Campus, Wuhan University of Technology, \\ 430070, Wuhan, Hubei, China. Tel: 86-150-0273-4362. E-mail: mkhitaryan_davit@yahoo.com
}

Received: February 13, 2014

Accepted: March 8, 2014

Online Published: March 10, 2014

doi:10.5430/jbar.v3n1p38

URL: http://dx.doi.org/10.5430/jbar.v3n1p38

\begin{abstract}
Nowadays brands play significant role in our economy and culture, brands seen as "cultural accessories and personal philosophies". The process of creating brand is the value addition technique that shows an image of the commodity, corporation and the country generally. Considering the fact that many new car brands in the recent years are becoming well known in China, car industry is chosen to study the problem effectively. The purpose of this paper is to find out valuation models of brand equity for automotive sector. The fruits of research tell us, for building brand equity, the brand loyalty and brand preference plays significant role. The brand equity's elements should be logical in their conduct in order to be understood and valued the true image of the company by consumers. The study delivers factual results of factors of brand equity with particular implication for Chinese automobile market.
\end{abstract}

Keywords: Brand loyalty, Brand relationship, Brand equity, Chinese car industry

\section{Introduction}

Brands have become very important parts of our economy and culture, now brands are characterized as "cultural accessories and personal philosophies". Brand is a name or a trademark associated with a product or company.

It's a fact that brand often becomes a commitment. It's proved that brands can be value improvers and also shorten income. Every marketing specialist accepts the fact that brands can add significant value. Brand creating process is the value addition technique that shows an image of the product, the enterprise and the country generally.

Brand strategy supports businesses in reaching their planed performance. Topic of brand equity has got high consideration for research recently. The research of brand equity is becoming more and more common, as some marketing specialists concurred that brands are one of the worthiest assets a firms posses. Consequently, current marketing research tries to manage brand equity and conceptualise measure in a way that drives brand market performance and assists companies in making strategic decisions. The study brings out an experimental results of the factors of brand equity with particular implication in Chinese automobile sector.

Brand equity is a phrase used in the marketing industry which describes the value of having a well-known brand name, based on the idea that the owner of a well-known brand name can generate more money from products with that brand name than from products with a less well known name, as consumers believe that a product with a well-known name is better than products with less well known names (Aaker David A. 1991).

According to Aaker (1991), "brand equity is a set of brand asset and liability connected to a brand, its name and logo add to or deduct from the value provided by a product or service to a company and/or to the company's consumers".

Brand equity is strategically crucial, but famously difficult to quantify. Many experts have developed tools to analyze this asset, but there is no universally accepted way to measure it. As one of the serial challenges that marketing professionals and academics find with the concept of brand equity, the disconnect between quantitative and qualitative equity values is difficult to reconcile. Quantitative brand equity includes numerical values such as profit margins and market share, but fails to capture qualitative elements such as prestige and associations of interest.

Customers' knowledge about a brand causes producers react differently or change suitably good measures for the brand marketing. 


\subsection{Review of Literature}

Brand equity can be looked into two different perspectives - financial and customer based. Financial asset value, the first perspective of brand equity is not discussed in this paper, which builds the business franchise. The outcome of customer-based brand equity will be measured by this method.

At first, brand equity was conceived to be comprised of customers' identification of brand which contain brand awareness, image and knowledge. As mentioned previously, brand equity is considered as having of 2 elements brand value and brand strength. The brand strength is our focus, which represents the brand identification held by the brand's consumers. In the 1990s, the subject of the brand equity came up as one of the most important fields of marketing management, according to Cathy et al (1995). This paper investigates some of the consequences of brand equity. Specifically, it investigates the effect of brand equity on purchase intentions and customer preferences. Two sets of brand were used, for comparative purposes, the first one is household cleansers, mainly with lower risk product sector and the other one is from service sector distinguished with pretty high functional and financial risks (hotel). Based on consumer reports raiting each category reckons two objectively similar brands, but over the past decade their investment in advertising spending have been obviously different. Across both sets, the brand which has higher advertising budget created considerably higher levels of brand equity. In turn, the brand with higher equity in each set yielded considerably greater preferences and purchase intentions.

The findings show positive relationships between brand equity, purchase intentions and brand preference, with a moderation effect of switching cost affecting the relationship between purchase intentions and brand equity. Particularly, for consumers with low switching costs it's not substantial the effect of brand equity on purchase intentions.

Kyung Hoon (2008), proposed his works concerning to the marketers in health care industry, who confront specific challenges universally, the role of the health care sector plays in committing commonwealth. In Korea the marketing of medical centers is very hard, because country's law forbids clinics in making advertisement. Thus, Korean hospitals depend strongly on customer relationship management (CRM). This paper determines fice factors that affects the building process of brand equity through successful customer relationship, customer satisfaction, trust, relationship commitment, brand awareness and brand loyalty. An experimental test of the relationships among these factors recommends if hospitals can manage their customer relationship well they would be accomplishing in establishing positive image and brand equity.

According to Chang (2009), the antecedents of brand equity are regarded to be brand image and brand attitude, and the consequences of brand equity are conceived to be purchase intentions and brand choice. The paper focuses on service brands, choosing eighteen from three service sections. A structural comparison model is shown. Which projects a proper relevance to the study constructs as well as the relationship among brand equity and brand image, brand equity and brand attitude. The effect of brand equity on purchase intentions and consumer preference is settled also, which tends to validate the projected investigation structure.

Brand perception is the outcome of brand positioning, which can be collected from different channels like marketing communication efforts, customer experiences, and word of mouth. It's obvious that brand perception is very important as companies are spending huge amount of money on brand measurement and development. Along with we know very little about the relationship between consumer behavior including consumer loyalty and brand perception. In order to perform empirical study two hypotheses have been tested about the connection between brand loyalty and brand perception. In the beginning, the study projects less proof that any one brand construct is more applicable and linked to brand loyalty than other brand constructs. Later on, the research discovers that higher number of attribute association with brand brings to higher brand loyalty. Besides, shows that brand uniqueness is vital in catching the buyers attention nevertheless, the source to build that uniqueness is upmost important in catching the buyers attention. Moreover, this research discusses brand development's short and long term strategies.

In this study, brand preference on segment B, CAIC Motors automobiles, showed that strong brands quality increase credence in intangible goods allowing consumers to imagine and understand them better. The brand preference for SAIC Motors segment B automobiles is researched by applying organized questioning plan to 150 car owners in Wuhan. SAIC Motors must take the advancement to offer new models considering the preference of consumers. While the consumer receives satisfaction and can make her/his living standard and life quality better, the trader benefits from brand experience that consumer receives and can create a surplus after ensuring satisfaction to the customer. 
This research observes the customer preference of international brands versus domestic brands in Chinese automobile industry. Customer brand perceptions have significant implications in marketing. Customer's preference towards domestic and international brands is researched by applying structured interview schedule with 150 consumers in Wuhan city. The results of the research suggested that the customers who owned international car brands, chose their car brands because of the factors such as worldwide reputation, global presence, and quality of being made in foreign countries. Customers have favorable belief about the country, where consumers use to consider such determinants as higher quality, technological developments, innovation and so on, to the country where the brand is originated. Customers who possessed domestic brands assessed the domestic brand in favorable way, in which they apt to connect the brand to China's robust car industry which produces valuable and technologically competent automobiles.

Therefore, literature review exposes that on brand equity most of the researches have done on Fast Moving Consumer Goods and service sector units. The paper concentrates on long lasting products associated to car industry, particularly passenger cars. In addition, the review of literature clearly tells that the research were centered on creating and conceiving brand equity without general agreement in what way to evaluate the brand equity or which constructs to involve in the evaluation process. As a result, there is an immediate need to find out brand equity attributes in a way that would permit scholars to effectively analyze and experimentally measure the main determinants related to brand equity performance.

\subsection{Problems of the Study}

Corporations are very incisive in advertising brands and building brand value to show their goods and be able to stay in the market in the international competitive environment. This can be gained with the help of brand equity. Therefore, it's necessary to find out the factors and assessment of brand equity and its connotation on value of company.

Being the abstract nature of the theory, it's hard to assess brand equity and ensure the value of the company. Because of this specific characteristic we have decided to research on brand equity. To research about subject in effective manner, automobile industry is selected taking into consideration the rise of many new car brands recently.

The objectives of our research are: to find out the factors determining brand equity in the automobile sector and to create consumer based brand equity model.

\section{Research Methodology}

The research is an experimental study with using primary and secondary data. The elaborated study should be performed with the help of structured interview schedule from among automobile owners in order to draw out primary data about brand equity. In the other hand, information from the secondary sources would be gathered also to evaluate the brand equity raised by chosen automobile producing firms. For gaining primary data in depth interview has been used in this specific research. Survey ethnics was selected to interpret the belief of domestic and international brand automobile users. Consumers' choice for domestic and international brands was investigated by applying structured interview schedule with 200 consumers in Wuhan. For choosing sample respondents researcher have selected cluster-sampling methods. The wholesalers of chosen automobile brands are referred as clusters. Based on the review of literature, author suggested for brand equity with several dimensions: brand relationship, brand knowledge and brand application.

\subsection{Reliability Analysis}

Table 1. Reliability Analysis

\begin{tabular}{lcc}
\hline Hypothesize & Alpha & N of Questions \\
\hline Brand application & 0.87 & 12 \\
\hline Brand knowledge & 0.75 & 3 \\
\hline Brand loyalty & 0.77 & 3 \\
\hline Brand preferences & 0.86 & 4 \\
\hline Brand relationship & 0.84 & 7
\end{tabular}

In order to analyze the credibility of census elements applied in the survey we used Cronbach's alpha, the results of which are as follows: Brand knowledge construct includes 3 elements on familiarity, recognition and awareness. Brand application construct includes twelve elements covering prestige, value and quality. Brand relationship 
measure integrates consumer satisfaction and consumer loyalty, and after all brand equity measure includes all 30 elements. Hence, it's a satisfactory level when alpha aligned from 0.7 to 0.95 . A scale of alpha is considered reliable if it is $>0.7$, according to Nunnally.

\subsection{Brand Knowledge}

Three constructs forms the brand knowledge: brand recognition brand familiarity and brand awareness. Brand awareness refers to customers' ability to recall and recognize the brand under different conditions and link to the brand name, logo, and so on to certain associations in memory. It consists of both brand recognition and brand recall. Familiarity measure suggested by Simonin and Ruth (1998) is "formed of three 5 point semantic differentials designed to evaluate a person's familiarity with a particular brand name".

\subsection{Brand Application}

Four constructs composes the brand application: prestige, value, affect, and quality. Chaudhuri and Holbrook (2001) adapted a scale called "affective response to brand", evaluating the degree of positive affect a customer has for a brand. The "prestige" attribute is assessed applying a scale named "prestigiousness' suggested by Sood and Bridges (1999). The scale assess the level of customers' consideration about particular item, being first class and luxurious. The research uses the scale to contest of brands. The "perceived quality" scale applied in the survey was adapted by Aaker \& Keller (1992) in a research that centered on core brands and evaluation of brand extensions. The scale was changed a little to be suitable to the contest of research that centered on core brands and evaluation of brand extension. The "perceived value" attribute is assessed by a scale adapted by Sweeney and Sotar, attesting to evaluate the utility derived from the anticipated economic value of specific brand.

\subsection{Brand Relationship}

Two constructs comprises the brand relationship: consumer loyalty and satisfaction. Consumer satisfaction scale measures the degree of satisfaction a customer receives from the brand's performance. As long as the scale by Tsiros and Mital in 2000, requested answerers to anticipate the response of others based on knowledge, the survey uses this scale for self-reporting intentions. The construct of consumer loyalty is assessed applying a scale adapted Donthu and Lee (2000). This scale tries to capture customer's general loyalty to a certain brand.

\subsection{Brand Preference and Brand Loyalty}

The construct of brand preference is scaled by one of the researches done from Sirgy (1996) to assess self-image congruency. This measure correlates the referent brand with focal brand. The research correlates other competing brands with the focal brand showed in the study.

Behavioral intention scale, adapted by Cronin, Brady and Hult in 2000, measures brand loyalty construct. The scale assess a possibility that customer would use some product again. In the survey this scale is applied in the context of brands.

\subsection{The Car Brands}

The aim of this paper is to concentrate on the Chinese automobile industry, particularly the 3 segments of vehicles A, $\mathrm{B}, \mathrm{C}$ segment are keeping price as criterion. Currently there are nearly 50 automobile producers in Chinese automotive industry. Our data for research are from VW, Mercedes Benz and SAIC Motors. According to Bloomberg, in 2013 Volkswagen occupied 14.6\% share of the market for passenger cars in China, SAIC Motors 10.6\% market share and Mercedes have 9.8\% market share. In total the foreign brands are occupied $55.7 \%$ market share and Chinese domestic brands have only $44.3 \%$ market share.

\section{Results}

Table 2 shows individual characteristics of the chosen respondents. The age group between 31 to 40 with the sample size of 88 represents $44 \%$, which is the maximum $\mathrm{N}$ of respondents. The age group of 21 to 30 years is $36 \%$ of the respondents and minimum number of answerers is in the age group of 40 and above with the sample size of 30 representing $15 \%$. Based on sex-wise categorization the larger number of answerers are male with sample size of 148 representing $74 \%$ and rest are female answerers. Likewise, larger number of answerers are married with sample size of 128 representing $64 \%$ and the rest are not married. Table 2 obviously shows the educational qualifications, $15 \%$ answerers is up to school level, $51 \%$ of the answerers who have educational qualification undergraduate and rest $34 \%$ of the answerers have educational qualification postgraduate and higher. We can see in Table 1 , that $56 \%$ of the answerers are the owners of business, government employees are $24 \%$ and remaining $20 \%$ of the answerers are private employees. Out of 200 answerers, larger number of the sample $50 \%$ are shown 100k RMB and more income group. 
Table 2. Demographic profile of the sample

\begin{tabular}{cccc}
\hline Details & Categorization & N of answerers & \% \\
\hline Age & Below 30 & 82 & 41 \\
& $31-40$ & 88 & 44 \\
& $41-50$ & 30 & 15 \\
\hline Sex & Male & 148 & 74 \\
& Female & 52 & 26 \\
\hline Marital Status & Married & 128 & 64 \\
& Unmarried & 72 & 36 \\
\hline Educational & School level & 30 & 15 \\
Status & Undergraduate & 102 & 51 \\
& Postgraduate \& & 68 & 34 \\
& above & & \\
\hline Occupation & Gov. Employee & 48 & 20 \\
& Private Employee & 40 & 30 \\
& Own Business & 112 & 50 \\
\hline Annual Income & Below 60 & 40 & 20 \\
(thousand & 60 - 100 & 60 & 30 \\
RMB/year) & Above 100 & 100 & 50 \\
\hline
\end{tabular}

In table 3 clearly represented different responses of car owners, we can see that $55 \%$ of the answerers use VW cars, $28 \%$ of the answerers use SAIC Motors automobiles and rest of the $17 \%$ of the answerers use Mercedes vehicles.

Table 3. Car Model

\section{Discussions}

\begin{tabular}{ccc}
\hline Car Brand & N of Responses & $\mathbf{\%}$ \\
\hline Volkswagen car & 110 & 55 \\
\hline SAIC Motors car & 56 & 28 \\
\hline Mercedes car & 34 & 17 \\
\hline Total & 200 & 100 \\
\hline
\end{tabular}

In table 4 the correlation matrix shows Pearson Correlation, which between each pair of metric variables in the example is important. It's mainly assigned to the big sample size. In the model this is a great evidence of the powerful relationships among constructs. All correlations are considered important, while some of them are very strong correlation.

Table 4. Correlation of Brand Equity Variables

\begin{tabular}{|c|c|c|c|c|c|c|c|c|}
\hline Details & BK & BQ & BV & $\mathrm{BP}$ & $\mathrm{CS}$ & $\mathrm{CL}$ & $\mathrm{BL}$ & BPR \\
\hline Brand knowledge & 1 & & & & & & & \\
\hline Brand quality & $.249 *$ & 1 & & & & & & \\
\hline Brand value & $.238^{*}$ & $.467 * *$ & 1 & & & & & \\
\hline Brand prestige & .022 & .079 & $.239 * *$ & 1 & & & & \\
\hline $\begin{array}{l}\text { Customer } \\
\text { satisfaction }\end{array}$ & $.345^{*}$ & .048 & $.266 * *$ & $.257^{*}$ & 1 & & & \\
\hline Customer loyalty & $.342 *$ & $.228 * *$ & $.395 * *$ & .092 & $.204 *$ & 1 & & \\
\hline Brand loyalty & .075 & $.263 * *$ & .045 & $.286^{*}$ & .158 & $.243^{*}$ & 1 & \\
\hline Brand preference & $.371 * *$ & $.257 * *$ & $.168^{*}$ & .081 & $.505^{*}$ & $.325 * *$ & $.266^{* *}$ & 1 \\
\hline
\end{tabular}


Table 5. Regression on Research Variable on Brand Equity

\begin{tabular}{lcc}
\hline Attributes of Brand Equity & Brand Loyalty & Brand Preference \\
\hline Brand knowledge & $0.19(.766)$ & $0.918(.014)$ \\
\hline Brand quality & $0.233(.001)$ & $0.72(.322)$ \\
\hline Brand value & $0.098(.000)$ & $0.267(.000)$ \\
\hline Brand prestige & $0.368(.000)$ & $0.86(.269)$ \\
Customer loyalty & $0.081(.246)$ & $0.116(.18)$ \\
\hline Customer satisfaction & $0.113(.002)$ & $0.218(.002)$ \\
\hline $\mathrm{R}^{2}$ and adjusted $\mathrm{R}^{2}$ F statistics & $0.359 \& 0.33521 .214(0.00)$ & $0.308 \& 0.27616 .129(0.00)$ \\
\hline
\end{tabular}

The data above are standardized regression weights and lower brackets are important values. About $32 \%$ of the variance in brand preference was stated in table 5 model $1 \mathrm{R}^{2}=29 \%$. Customer satisfaction and brand quality are the most significant attributes in illustrating brand choice. It shows that sources of brand quality and consumer satisfaction are strongly depended on as inputs for supporting brand choice by the answerers. In model 2, brand value, brand quality, customer satisfaction and brand prestige can describe brand loyalty better compared to other elements. This exhibit shows that about $36 \%$ adjusted $\mathrm{R}^{2}=34 \%$ of variance. Equity of brand has substantially good influence on both brand loyalty and brand preference.

\section{Conclusions}

The research constitutes to increasing number of the writings on brand equity through analyzing how brand applications, brand knowledge, brand preferences, brand relationships and brand loyalty affects in creating brand equity. The organization need to be interested in measuring the level of consumers' dependence on a brand when trying to make strong brand equity. The brand strength relies on the consumer perception. Loyal and satisfied consumers show positive brand perceptions. During the fierce competition, it is extremely important for the company to solidly assess determinants that are not only significant in building powerful brand equity but also support them for reaching consumer loyalty and satisfaction. The outcomes of the research exhibits that brand loyalty and brand preference plays serious role in building brand equity. The elements of brand equity should be consistent in their actions so that coherent image of the company is recognized and valued by consumers.

\section{References}

Aaker David \& Kavin Keller. (1992). The Effects of Sequential Introduction of Brand Extension. Journal of Marketing Research, 29, 1 (February) 35-50. http://psycnet.apa.org/doi/10.2307/3172491

Cathy J. Cobb-Walgren, Cynthia A. Ruble. (1995). Brand Equity, Brand Preference, and Purchase Intention. Journal of Advertising, Vol. 24, N 3, pp 25-40. http://dx.doi.org/10.1080/00913367.1995.10673481

Chang, Ya Ming. (2009). The impact of Brand Equity on Brand Preference and Purchase Intentions in the Service Industry. The Service Industry Journal. 29; 12(2009), pp. 1687-1706. http://dx.doi.org/10.1080/02642060902793557

Ching Fu Chen, Yu Yu Chang. (2008). Airline Brand Equity, Brand Preference and Purchase Intentions - The Moderating Effects of Switching Costs. Journal of Air Transport Management, 14 (2008), pp. 40-42. http://dx.doi.org/10.1016/j.jairtraman.2007.11.003

Cronin, Jr., Joseph, Michael K., Tomas Hult. (2000). Assessing the Effects of Quality, Value and Customer Satisfaction on Consumer Behavioral Intentions in Service Environments. Journal of Retao, 79(2), 193-218. http://dx.doi.org/10.1016/S0022-4359(00)00028-2

Keller, Kevin L. (1993). Conceptualizing, Measuring and Managing Customer-Based Brand Equity. Journal of Marketing. 57 (January), 1-22. http://dx.doi.org/10.2307/1252054

Ritter, T., Wilkinson, I. F., \& Johnston, W. (2004). Firms' Ability to Manage in Business Networks: A Review of Concepts. Industrial Marketing http://dx.doi.org/10.1016/j.indmarman.2003.10.016

Management. 33(3), 175-183. 
Rosenkopf, L., \& Schilling, M. A. (2007). Comparing Alliance Network Structure Across Industries. Strategic Entrepreneurship Journal. 1(3-4), 191-209. http://dx.doi.org/10.1002/sej.33

Simonin, Bernared L. \& Julie A. Ruth. (1998). Assessing the Spillover Effects of Brand Alliances on Consumer Brand Attitudes. Journal of Marketing Research, 35 (February), 30-42. http://dx.doi.org/10.2307/3151928

Sun, J., \& Tesfatsion, L. (2007). Dynamic Testing of Wholesale Power Market Designs: An Open-Source Agent Based Framework. Computational Economics. 30(3), 291-327. http://dx.doi.org/10.1007/s10614-007-9095-1

Welch, D., Welch, L., Wilkinson, I., \& Young, L. (1996a). Network Development in International Project Marketing and the Impact of External Facilitation. International Business Review. 5(6), 579-602. http://dx.doi.org/10.1016/S0969-5931(96)00029-7 